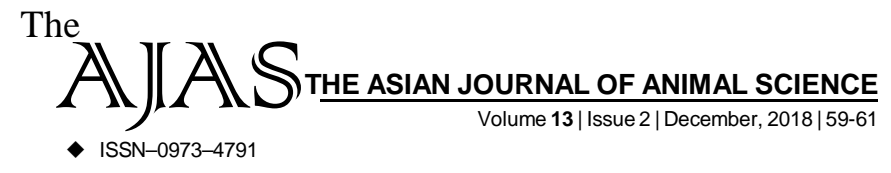

RESEARCH ARTICLE.

\title{
Histological and histochemical studies of epidermis in crossbreed cattle
}

\author{
P.J. Kapadnis and P. N. Thakur
}

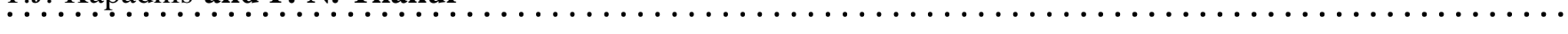

ABSTRACT...... The skin of crossbreed cow (Deoni x HF, $\mathrm{F}_{1}$ generation) histologiocally showed three layers as epidermis, dermis and hypodermis. The epidermis consisted of four types of layers from outer to inner side as Stratum carneum, Stratum granulosum, Stratum spinosum and Stratum basale. The keratinocytes were found in the Stratum carneum, melanocytes and langerhans cells were found in Stratum spinosum and Stratum basale. The markels cells were round in basal layer of the epidermis in heifers. The papillomatus epidermis was the down growth of the epidermis between the dermal papillae.

Author for Corresponding P.N. Thakur Department of Veterinary Anatomy and Histology College of Veterinary and Animal Sciences, Parbhani (M.S.) India

\section{KEY WORDS....... Histology, Histochemistry, Skin, Epidermis, Crossbreed cattle}

HOW TO CITE THIS ARTICLE - Kapadnis, P.J. and Thakur, P.N. (2018). Histological and histochemical studies of epidermis in crossbreed cattle. Asian J. Animal Sci., 13(2): 59-61. DOI : 10.15740/HAS/ TAJAS/13.2/59-61. Copyright@2018:HindAgri-Horticultural Society.

ARTICLE CHRONICLE - Received : 28.08.2018; Revised : 07.11.2018; Accepted : 16.11.2018 